\title{
Regulation of Intestinal Lactase in Adult Hypolactasia
}

\author{
Mark Lloyd, Gregory Mevissen, Michael Fischer, Ward Olsen, David Goodspeed, \\ Michele Genini, Werner Boll, Giorgio Semenza, and Ned Mantei \\ Gastroenterology Research Laboratory, William S. Middleton Memorial Veterans Hospital, Madison, Wisconsin 53705; \\ Department of Medicine, University of Wisconsin, Madison, Wisconsin 53792; and Department of Biochemistry II, \\ Swiss Federal Institute of Technology, Eidgenössische Technische Hochschule Zentrum, CH-8092 Zurich, Switzerland
}

\begin{abstract}
Relative deficiency of intestinal lactase activity during adulthood, adult hypolactasia, is a common condition worldwide. We studied the regulation of lactase-phlorizin hydrolase in normal and adult hypolactasic subjects by correlating transcript abundance in intestinal biopsies with relative synthetic rates for the protein in cultured intestinal explants. After metabolic labelling studies in six subjects, precursor lactase-phlorizin hydrolase was identified in amounts directly proportional to the enzyme-specific activity suggesting that levels of intestinal lactase are regulated by synthetic rate. Total intestinal RNA was extracted from biopsies of these subjects and three hypolactasic adults who had participated in previous biosynthesis studies. Transcript levels were markedly reduced in deficient subjects who demonstrated diminished lactase-phlorizin hydrolase synthesis. The sequence of $1 \mathrm{~kb}$ of 5 -flanking region of the lactase-phlorizin hydrolase gene was determined in two hypolactasic subjects and two controls. No sequence variability was identified to account for differences in mRNA levels or biosynthetic rates between the two groups.

A single hypolactasic subject previously characterized as demonstrating delayed posttranslational processing, showed message levels intermediate between other deficients and controls. These results suggest that in the majority of our subjects, pretranslational mechanisms account for the predominate regulatory control of lactase-phlorizin hydrolase expression in the proximal intestine. (J. Clin. Invest. 1992. 89:524-529.) Key words: lactase • lactase deficiency • adult hypolactasia
\end{abstract}

\section{Introduction}

\section{Regulation of intestinal lactase in adult hypolactasia}

Lactase-phlorizin hydrolase (LPH) ${ }^{1}$, the $\beta$-glycosidase complex, is an integral protein of the intestinal brush-border membrane. The disaccharidase activity associated with the complex is responsible for the hydrolysis of lactose, the major carbohy-

Portions of this work were presented at the annual meeting of the American Gastroenterological Association, New Orleans, 19-22 May 1991, and have appeared in abstract form (1991. Gastroenterology. 100:226A)

Address correspondence to Mark Lloyd, M.D., Gastroenterology Research Laboratory, Middleton Veterans Administration Hospital, 2500 Overlook Terrace, Madison, WI 53705.

Received for publication 5 June 1991 and in revised form 6 November 1991.

1. Abbreviations used in this paper: LPH, lactase-phlorizin hydrolase; PCR, polymerase chain reaction.

The Journal of Clinical Investigation, Inc.

Volume 89, February 1992, 524-529 drate constituent of dietary milk, to its component monosaccharides, glucose and galactose, which in turn can be absorbed by the intestinal mucosa. LPH is unique among intestinal hydrolases in its precipitous decline in activity coincident with the onset of weaning in most mammalian species. The molecular mechanisms responsible for this phenomena have been the focus of recent studies, but controversy persists as to whether the primary control of LPH gene expression in the intestine occurs at the level of transcription or during subsequent cellular events (1-3).

In contrast to other mammals, a substantial portion of the human population maintains high levels of intestinal lactase activity throughout adulthood. Those individuals who exhibit physiologic decline in the enzyme activity with maturation are described as demonstrating adult lactase deficiency. The biosynthesis of LPH in the setting of adult lactase deficiency has recently been studied and two distinct phenotypes reported (4, 5). Phenotype I is characterized by reduced synthesis of precursor LPH while the mechanism of decreased lactase activity in phenotype II is associated with ample precursor synthesis but reduced conversion of the protein to its mature molecular form. The alteration in LPH biosynthesis in phenotype I deficiency suggests a possible mechanism of regulation at the level of the LPH message. A recent study of levels of LPH-specific mRNA in human intestine, however, has reported poor correlation with enzyme activity in control and hypolactasic subjects, and posttranscriptional control of human LPH gene expression was postulated (1).

To further elucidate the mechanisms that control LPH gene expression, we have determined levels of LPH mRNA in both deficient and control subjects and report the results in concert with the findings from biosynthetic labelling studies in these same subjects. Our results show parallel reductions in lactase-specific activity and message levels in those subjects in whom biosynthetic studies have demonstrated decreased synthesis (phenotype I deficiency). In addition, we have determined the sequence of more than $1 \mathrm{~kb}$ of the 5 -flanking region of the LPH gene from two of these phenotype I-deficient subjects and two controls. We found no variability within this region, however, to account for differences in message levels between the two groups.

\section{Methods}

Subjects. Nine volunteers underwent endoscopic duodenal biopsy. Three subjects had participated in prior biosynthesis studies and had been characterized as demonstrating phenotype I (two subjects) or phenotype II (one subject) lactase deficiency. With the exception of lactose intolerance in some, the volunteers had no clinical, endoscopic, or histologic evidence of intestinal disease. Biopsies were flash frozen in liquid nitrogen for subsequent RNA extractions and assays of mucosal protein content (Bio-Rad Laboratories, Richmond, CA) and disacchari- 
dase activities (6) (Table I). Two of five lactase-deficient volunteers and two control subjects had blood drawn for studies directed at the identification of regulatory elements of the lactase gene through DNA amplification and sequencing. Additional biopsies were obtained from the six subjects who had not undergone previous metabolic labelling studies, and were immediately prepared for maintenance in organ culture as described below.

Metabolic labelling. Metabolic labelling studies were performed as previously reported by us $(4,7,8)$. Briefly, duodenal biopsies were equilibrated for $1 \mathrm{~h}$ in tissue culture medium, and then continuously exposed to $400 \mu \mathrm{Ci}\left[{ }^{35} \mathrm{~S}\right]$ methionine for periods of 1,5 , and $20 \mathrm{~h}$. The radiolabelled explants were homogenized in PBS with $1 \%$ Triton $\mathrm{X}-100 \mathrm{pH}$ 7.5. Homogenization and all subsequent processing steps were performed in the presence of the following protease inhibitors: aprotinin $(1 \mu \mathrm{g} / \mathrm{ml}), \operatorname{PMSF}(1 \mathrm{mM}), \operatorname{EDTA}(100 \mu \mathrm{M})$ and leupeptin $(10$ $\mu \mathrm{g} / \mathrm{ml})$. An aliquot of whole homogenate was used to determine radioactivity incorporated into total protein (4).

Immunoprecipitation. Triton $\mathrm{X}-100$-solubilized homogenates were centrifuged at $27,000 \mathrm{~g}$ for $1 \mathrm{~h}$. The supernatants were precleared with Pansorbin (Calbiochem-Behring Corp., La Jolla, CA), and their volumes adjusted to contain equal amounts of radiolabelled total protein. Immunoprecipitation was carried out by adding an excess of monoclonal antibodies ( $\mathrm{H} 31 \mathrm{C} 4 \mathrm{C} 3$ ), directed against human $\mathrm{LPH}$, to the precleared, volume-adjusted samples (4). The adequacy of precipitation was verified by lactase assays on samples both before and after immunoprecipitation.

$S D S-P A G E$. The immunoprecipitates were solubilized under reducing conditions (4) and applied to $5 \%$ polyacrylamide gels for electrophoresis using the buffer system of Laemmli (9). Gels were developed with silver stain using the technique of Heukeshoven (10) then treated with EN ${ }^{3}$ HANCE (New England Nuclear, Boston, MA), dried on filter paper, and exposed to Kodak X-OMAT AR film (Eastman Kodak, Rochester, NY) for $10 \mathrm{~d}$ at $-70^{\circ} \mathrm{C}$ to yield the completed fluorograms. Fluorogram band densities were assessed with the scanning densitometer (GS 300; Hoefer Scientific Instruments, San Francisco, CA).

$R N A$ extraction. Total cellular RNA was isolated from intestinal biopsies using the single step guanidinium thiocyanate-phenol-chloroform extraction method of Chomczynski and Sacchi (11). After the extraction, the RNA pellet was washed twice in $75 \%$ ethanol, dried under vacuum, and stored at $-70^{\circ} \mathrm{C}$ after dissolution in diethyl pyrocarbonate-treated water. 260/280 absorbance ratios were determined on a spectrophotometer (240; Gilford Instrument Laboratories, Inc., Oberlin, $\mathrm{OH}$ ).

RNA analysis. 10- $\mu \mathrm{g}$ samples of RNA were electrophoresed according to Maniatis et al. using $0.9 \%$ agarose and $0.74 \mathrm{M}$ formaldehyde (12). The gels were treated with $0.05 \mathrm{M} \mathrm{NaOH}$ for $30 \mathrm{~min}$, neutralized in $0.5 \mathrm{M}$ Tris, $\mathrm{pH} 7.0$, and then soaked in $1 \times \mathrm{SSC}(8.9 \mathrm{~g} \mathrm{NaCl}, 4.4 \mathrm{~g}$ $\mathrm{Na}_{3}$ citrate per liter, $\mathrm{pH} 7.0$ ). RNA was transferred to a Hybond-N ny-

Table I. Disaccharidase Activities in the Study Population

\begin{tabular}{cccc}
\hline & \multicolumn{2}{c}{ Mucosal specific activity* } & \\
\cline { 2 - 3 } Subject & Lactase & Sucrase & $\begin{array}{c}\text { Sucrase/lactase } \\
\text { ratio }\end{array}$ \\
\hline 1 & 2.3 & 30.3 & 13.1 \\
2 & 3.0 & 35.0 & 11.6 \\
3 & 3.0 & 47.1 & 15.7 \\
4 & 4.5 & 158.9 & 33.5 \\
5 & 6.0 & 56.0 & 9.3 \\
6 & 12.9 & 17.4 & 1.4 \\
7 & 16.6 & 36.3 & 2.2 \\
8 & 19.0 & 34.1 & 1.8 \\
9 & 59.3 & 91.8 & 1.6 \\
\hline
\end{tabular}

* Units per gram protein. lon membrane (Amersham Corp., Arlington Heights, IL) using $20 \times$ SSC. The filter was then baked for $2 \mathrm{~h}$ at $80^{\circ} \mathrm{C}$.

Prehybridization was performed at $42^{\circ} \mathrm{C}$ in $50 \%$ formamide, $1 \%$ SDS, $6 \times$ SSC, $5 \times$ Denhardt's reagent, $1 \mathrm{mM}$ EDTA, and $100 \mu \mathrm{g} / \mathrm{ml}$ of denatured salmon sperm. Hybridizations to lactase mRNA were performed overnight using the pHLac- 5 cDNA isolated and sequenced by Mantei et al. (13). The cDNA was labelled using the "Prime-a-Gene" system (Promega Biotec, Madison, WI). Membranes were washed three times with $1 \%$ SDS and $1 \times$ SSC for $10 \mathrm{~min}$ at room temperature and three times for $40 \mathrm{~min}$ at $70^{\circ} \mathrm{C}$. Autoradiograms were generated by exposure to Kodak X-OMAT AR film for $1-3 \mathrm{~d}$ at $-70^{\circ} \mathrm{C}$.

Slot blot studies were performed using a Bio-Slot apparatus (BioRad). $15 \mu \mathrm{g}$ of RNA was denatured in $6 \%$ formaldehyde and $6 \times$ SSC with heating at $60^{\circ}$ for $15 \mathrm{~min}$ followed by cooling on ice. 1.5- and 3.0- $\mu \mathrm{g}$ samples were applied to the membrane which was then prepared for hybridization, autoradiography, and densitometry as above. This same membrane was also hybridized with a human $\beta$-actin probe used in an identical fashion (14). Before repeat hybridizations, the membrane was treated with $0.1 \%$ SDS at $95^{\circ} \mathrm{C}$ with autoradiographic verification of removal of the probe.

DNA sequencing. DNA was prepared from blood (15). Segments of DNA were amplified by polymerase chain reaction (PCR) and "singlestranded PCR" (16) as described earlier (17), and then directly sequenced by a slight modification (17) of the dideoxy method (18). The PCR and sequencing primers listed in Table II were synthesized with a gene assembler (Pharmacia Inc., Piscataway, NJ).

\section{Results}

Metabolic labelling. Results of studies of the biosynthesis of LPH in subjects 2,3 , and 5 have previously been reported (4). Fig. $1 \mathrm{~A}$ displays a fluorogram generated after $1 \mathrm{~h}$ of continuous labelling in the six additional subjects. Radiolabel was initially incorporated into a $205-\mathrm{kD}$ precursor $\mathrm{LPH}$, the size corresponding to the high mannose form of the molecule. At this early time point, the relative band densities reflect synthetic rates with relatively little contribution from degradation of the protein. Fig. 2 demonstrates a linear relationship between synthesis and mucosal lactase-specific activity reinforcing our prior conclusion that, in general, the level of the enzyme in the intestine is dictated by synthetic rate (4). Accordingly, the reduced incorporation of radioactivity into LPH precursors characterizes subjects 1 and 4 as type I deficients.

Fig. 1, $B$ and $C$, displays fluorograms developed after 5 and $20 \mathrm{~h}$ of labelling, respectively. At $5 \mathrm{~h}$ mature $150-\mathrm{kD} \mathrm{LPH}$ can be identified though most of the radiolabel is distributed among the multiple molecular forms represented from 190 to $215 \mathrm{kD}$. Our previous work suggests that, in order of decreasing molecular size, these are the complex precursor $(215 \mathrm{kD})$, the high mannose precursor $(205 \mathrm{kD})$, and intermediates arising from the proteolytic processing of both of the precursor forms (205-190 kD). After $20 \mathrm{~h}$ of labelling, an additional, prominent band was identified at a molecular size estimated at $250 \mathrm{kD}$ (the molecular weight markers did not span this portion of the gel). Sterchi and colleagues identified a similar form of high molecular weight LPH and proposed that this band probably represents the dimeric form of the mature protein that escaped complete dissociation under the reducing conditions used in preparation for electrophoresis (5).

RNA analysis. Fig. 3 displays the Northern blot analysis for LPH mRNA from nine subjects who have collectively undergone metabolic labelling experiments in this and a prior study (4). Though equal quantities of RNA were transferred to the nylon membrane, the LPH message, represented by a $6-\mathrm{kb}$ 
Table II. Oligonucleotides Used in PCR and Sequencing

\begin{tabular}{lcccclc}
\hline Name & Strand & Length & PCR & Sequencing & \multicolumn{1}{c}{ Sequence } & Position \\
\hline 1. PCR1 & + & 21 & $*$ & & CATTCTGACTCCTGTATAACC & $-66 /-46$ \\
2. PCR2 & - & 20 & $*$ & & AAAGACCAACACAAAAACCT & 545/565 \\
3. PCR3 & + & 23 & $*$ & $*$ & GGTAATCGTTTCTTCAGACATT & 486/508 \\
4. PCR4 & - & 20 & $*$ & & TATCAGACTCCCAGTCTGAC & $1093 / 1112$ \\
5. SEQ1 & + & 17 & & $*$ & CTCACACCTGTAATCCC & $191 / 207$ \\
6. SEQ2 & - & 17 & & $*$ & AGAGATGGAGTTTTGCC & 276/292 \\
7. SEQ3 & + & 17 & & $*$ & TCTCGATCTCCTGACCT & ACCTGTAATTCCAGCACT \\
8. SEQ4 & - & 18 & & & & $835 / 852$
\end{tabular}

Sequences of the primers used to amplify overlapping segments of the $5^{\prime}$-flanking region of the LPH gene and for sequencing. The asterisks indicate whether a primer was used for PCR, for sequencing, or for both. The sequences are shown $5^{\prime}$ to $3^{\prime}$, with the $(+)$ or $(-)$ indicating whether the primer is plus or minus strand. The last column shows the location of the primer in the promoter region sequence of reference 17; PCR1 lies upstream of this region and was designed on the basis of unpublished data (W. Boll).

band, is obviously present in reduced amounts in lanes 1 through 5. Lanes 1 through 4 have been generated from subjects characterized as demonstrating phenotype I lactase deficiency on the basis of metabolic labelling while lane 5 is from the phenotype II subject. Fig. 4 demonstrates slot blot studies of these subjects' total intestinal RNA hybridized to the cDNA for human LPH. As a control, slot blot studies were also performed with a human $\beta$-actin cDNA that hybridizes to a single 2-kb transcript on Northern blot analysis. In each case slot densities were measured, and the level of LPH message,
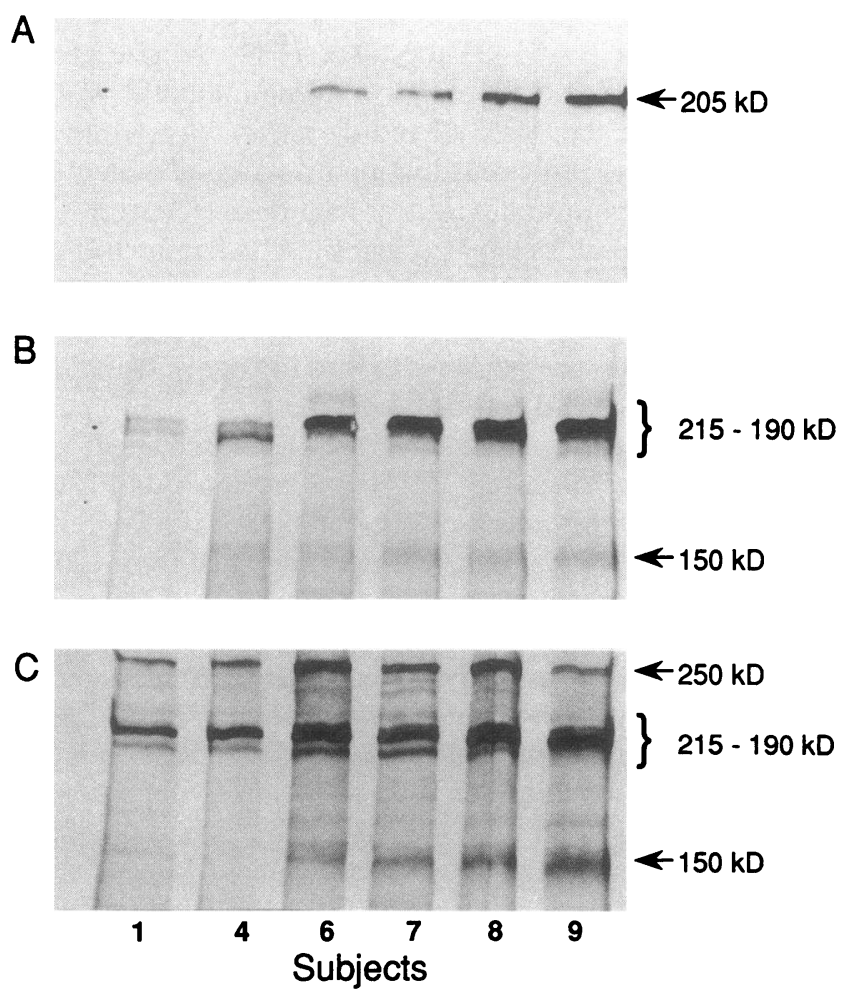

Figure 1. Fluorograms of immunoprecipitated LPH from continuous labelling studies. In $A$ (1-h labelling) LPH is initially recognized as the $205-\mathrm{kD}$ precursor protein. Significantly less radioactivity is incorporated into LPH in lactase-deficient subjects 1 and $4 . B$ and $C$ show accumulation of LPH in various molecular forms at 5 and $20 \mathrm{~h}$, respectively. corrected for $\beta$-actin, was plotted as a function of intestinal specific activity (Fig. 5). There is a direct relationship between enzyme activity and message levels in this set of subjects.

Sequence of the 5'-flanking region of the LPH gene in hypolactasic subjects and controls. The sequence of more than 1,000 nucleotides of the 5 '-flanking region of the cloned human LPH gene has been described (17). We used the polymerase chain reaction to rapidly resequence this region in DNA from subjects $1,4,8$, and 9. Two overlapping segments of DNA were amplified by PCR with the primer pairs PCR1+PCR2 and PCR3+PCR4 shown in Table II. The products were further amplified by single-stranded PCR (16) and then sequenced directly with the primers indicated in Table II. As a control, DNA from subject P2 of reference (17), who shows persistence of lactase and from whom the original chromosomal clones had been isolated, was also amplified and sequenced. Subjects 1,4 , 8 , and 9 proved to have identical sequences for more than $1 \mathrm{~kb}$ upstream of the cap site (from position +67 to -1070 in the coordinates of the cDNA sequence (13) or 1092 to -45 in the coordinates of the chromosomal DNA sequence) (17). There were two differences from the sequence of the original cloned

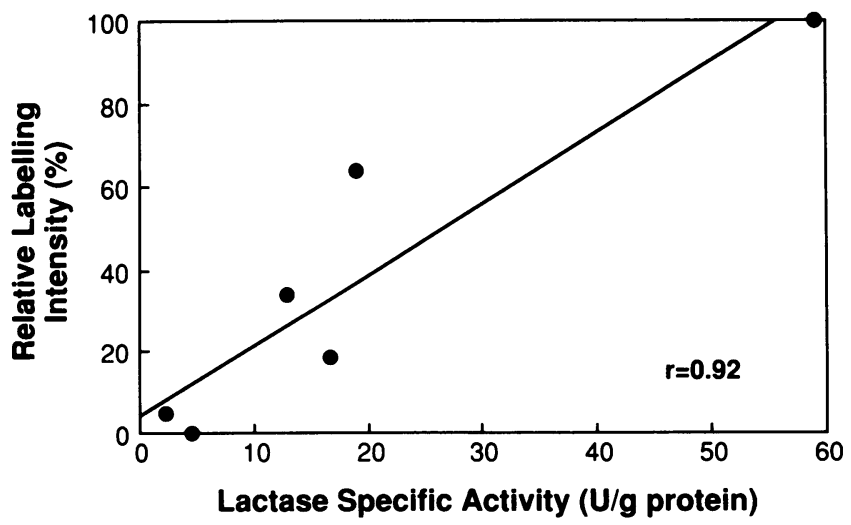

Figure 2. Labelling intensity as determined by densitometry of the bands from the 1-h fluorogram (Fig. $1 \mathrm{~A}$ ) plotted against lactase-specific activity. Labelling intensity is directly proportional to enzyme specific activity suggesting that the rate of synthesis is the primary determinate of the amount of the LPH present in the proximal intestine of these subjects. The reduced rate of synthesis in hypolactasic subjects 1 and 4 is characteristic of phenotype I lactase deficiency. 


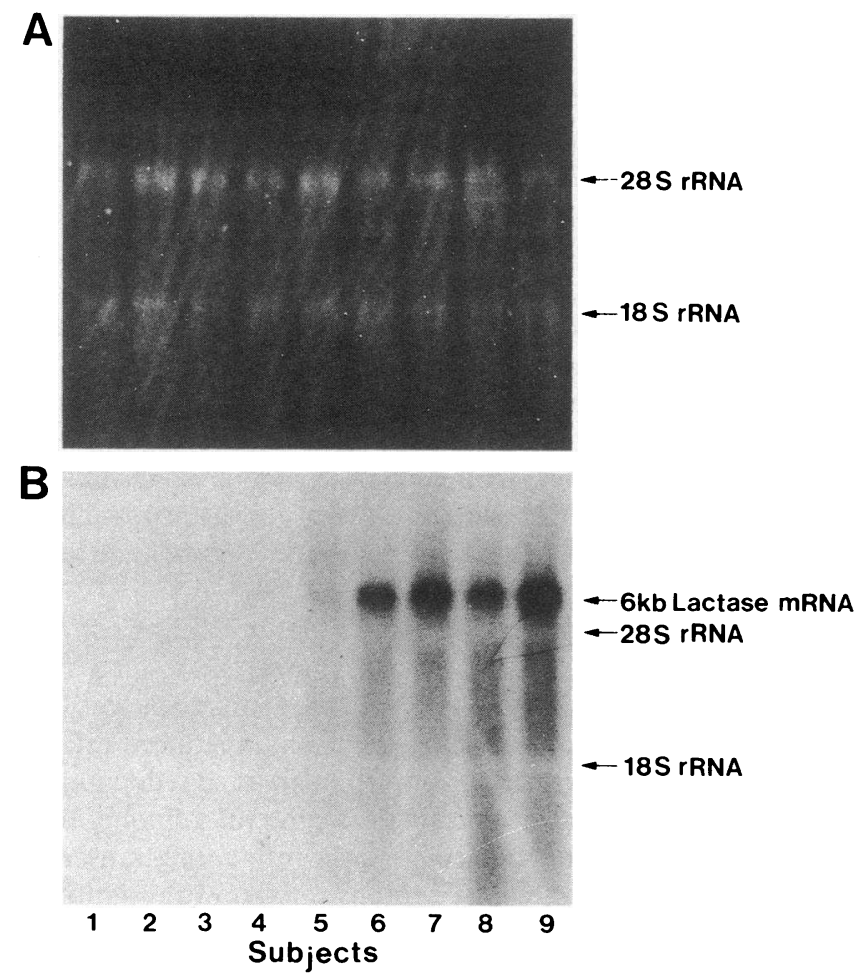

Figure 3. Northern blot analysis of total intestinal RNA from nine subjects who participated in metabolic labelling studies. UV transillumination demonstrates equal quantities of RNA applied to the ethidium bromide stained agarose gel $(A)$. After transfer and hybridization with the pHLac- 5 cDNA probe, LPH mRNA is recognized as a single 6-kb band of variable intensity $(B)$.

DNA (from subject P2), but these may be attributed to allelic variation, as DNA amplified from P2 by PCR also showed these differences on the noncloned allele (Table III). Thus no sequence variability within the first $1 \mathrm{~kb}$ upstream from the cap site can explain the different amounts of LPH mRNA found in subjects 1 and 4 versus 8 and 9 .

\section{Discussion}

Adult-type hypolactasia is a common disorder characterized by delayed loss of lactase activity to levels $5-10 \%$ of those of early childhood in otherwise normal intestine. This condition ap-

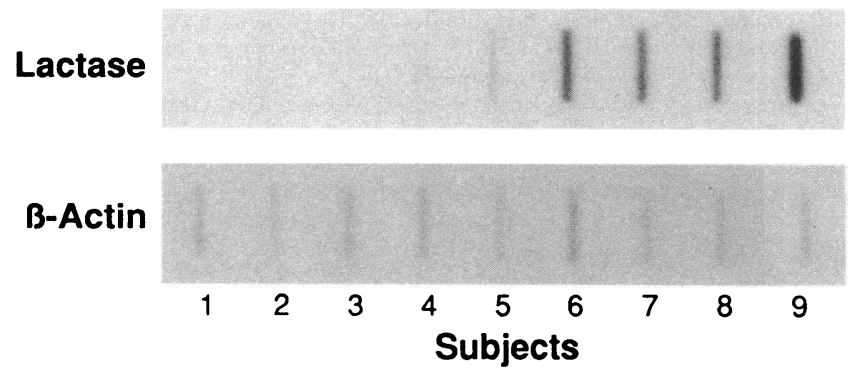

Figure 4. Slot blot analysis of mRNA levels for LPH and $\beta$-actin. Message levels for LPH are markedly reduced for phenotype I-deficient subjects 1 through 4 and of an intermediate value for the single phenotype II subject.

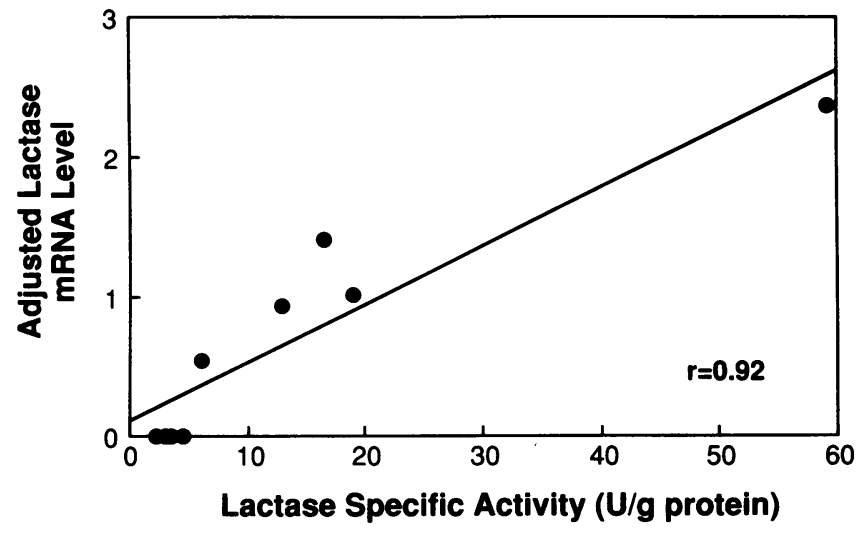

Figure 5. Adjusted LPH mRNA values plotted against lactase-specific activity. The LPH message levels (densitometry ratios of $\mathrm{LPH} / \beta$-actin from Fig. 4) are directly proportional to enzyme specific activity in the nine study subjects.

pears to parallel the situation in all other land mammals where there is a physiological decline in lactase activity coincident with weaning. The actual mechanism by which this genetically predetermined loss is regulated is unknown, though recent studies have provided insight into the nature the biosynthetic events $(4,5)$.

Using a system of metabolic labelling in organ culture, we isolated newly synthesized LPH from intestinal explants of subjects with adult hypolactasia and compared the recovery with that of control subjects in a quantitative fashion. All except one of our hypolactasic adults (subjects 1-4) have shown evidence of reduced synthesis of the protein as assessed by incorporation of radioactivity into immunoprecipitable LPH. We have previously designated adult hypolactasia arising from reduced synthesis as phenotype I deficiency (4). Similar findings of reduced LPH synthesis in this condition were recently reported by Sterchi et al. (5). Some of their subjects, in addition, showed delayed maturation of LPH associated with the accumulation of immunoreactive material in the Golgi region on immunoelectron microscopy. In contrast, we have studied one individual (subject 5) with adult hypolactasia who demonstrated synthesis of the protein at a rate exceeding that of the

Table III. Sequence Variability Upstream of the Human LPH Coding Region

\begin{tabular}{|c|c|c|}
\hline Source & Nucleotide $68^{*}$ & Nucleotide $467-474^{*}$ \\
\hline$\lambda$ hchrlac $7^{\ddagger}$ & ${ }^{66} \mathrm{TCTAT}^{70}$ & ${ }^{466}$ CAAAAAAAA-C $C^{475}$ \\
\hline $1 ; 4 ; 8 ;$ and $9^{\S}$ & TCẸAT & CAAAAAAAAAC \\
\hline $\mathbf{P} 2^{\S}$ & TCȲAT & CAAAAAAAA $\pm \mathrm{C}$ \\
\hline
\end{tabular}

The source of the sequenced DNA is indicated. Short stretches of sequence are shown, within which variable nucleotides are underlined (the variation shown as $A^{474}$ could be at any of positions 467 to 474 ). * Nucleotide positions in the coordinates of the promoter region sequence (17). ${ }^{\ddagger}$ Sequence of cloned DNA carried in clone $\lambda$ hchrlac7, representing one allele of subject P2. From (17). ${ }^{8}$ Sequences of PCRamplified DNA from indicated subjects (both chromosomes sequenced as a mixture).

$\mathrm{Y}$, cytosine or thymidine; ${ }_{-}^{*}$, adenine in one chromosome, no nucleotide in the other; -, gap added for alignment. 
control, but there was a marked reduction in the rate at which newly synthesized LPH was converted to its mature brushborder membrane form (4). We have designated hypolactasia as a result of a posttranslational maturation defect, phenotype II.

There is limited information concerning the levels of message encoding intestinal LPH in human intestine (1). With the same cDNA probe that we used, Sebastio et al. found poor correlation between LPH mRNA levels and enzyme activity in resected intestine from lactase-deficient and control Neapolitan subjects. On average the deficient population had message levels of approximately one-half the controls despite a much greater degree of disparity between intestinal enzymatic activities in the two groups. Our data, however, suggest that lactase mRNA levels are proportionately reduced in those individuals that have been identified as phenotype I deficients through biosynthesis studies. There are several possible explanations for the disparity between our findings and those previously reported. The tissues sampled in the present work were taken from the distal duodenum and proximal jejunum, and the enzyme activities are in accordance with values determined by previous studies of biopsy material from those sites (19). The Neapolitan study reported sampling from resected surgical specimens of jejunum, but in their lactase-deficient subjects the average sucrase activity and sucrase to lactase ratio were significantly greater than that we report. This suggests that analogous regions were not sampled. This may be of critical importance since animal studies have demonstrated variable correlation between levels of transcript and enzyme over the longitudinal axis of the intestine $(3,20)$. In addition, the effect of pathologic lesions (e.g., neoplasm, inflammation, obstruction) presumably in proximity to the site of surgical sampling cannot be fully assessed.

An additional possibility is that there are population differences in the manner by which LPH expression is controlled in hypolactasic adults. On the basis of their results Sebastio et al. postulated that LPH expression in the human intestine is controlled through posttranscriptional mechanisms. We have clearly identified such a mechanism in the phenotype II deficient subject described above (4). Levels of LPH transcript in this individual are intermediate when compared to phenotype I deficient and control subjects. In the absence of any phenotypic markers (short of biosynthesis studies) for type II deficiency, it is interesting to speculate that the hypolactasic Neapolitan subjects may have demonstrated a higher average level of LPH mRNA because of greater numbers of phenotype II individuals in the population sampled.

The case for genetic polymorphism in respect to adult hypolactasia has been strengthened by the recent identification of two populations of deficient individuals by immunohistochemistry (21). Among subjects studied in this fashion, those with adult hypolactasia were characterized by either absent mucosal staining with anti-LPH monoclonal antibodies or by a mosaic pattern showing patchy expression of the protein by individual enterocytes scattered over the villi. This observation has yet to be correlated with determinations of message levels or parallel biosynthetic studies that might provide a unifying perspective.

Since it appeared that our phenotype I-deficient subjects demonstrated control of LPH expression on the basis of the quantity of transcript present, we hoped to identify regulatory elements within the promoter region of the $\mathrm{LPH}$ gene to ac- count for differential rates of transcription. We determined the sequence of more than $1 \mathrm{~kb}$ of the 5'-flanking region of the LPH gene for four of our subjects, 1 and 4 with hypolactasia, and 8 and 9 with persistence of lactase. No variability was found within this region. The slight differences found compared to the subject described previously (subject P2; Table III) are likely to represent allelic variations and do not fall in any identifiable promoter sequence element (17). As regulatory elements can lie both far upstream and downstream of a gene (for example, the dominant control region of the globin gene locus is more than $50 \mathrm{~kb}$ upstream and an enhancer is downstream of the $\beta$-globin gene) (22), it is clear that the difference we seek could be much further upstream, or could be downstream, from the cap site of the LPH gene. Furthermore, the possibility that steady-state transcript levels are controlled by relative rates of degradation cannot be excluded.

In conclusion, these data serve to reinforce our previous observations that adult hypolactasia may arise as a result of two distinct mechanisms of regulatory control. Individuals who develop lactase deficiency as a consequence of a reduced rate of LPH synthesis, demonstrate a coordinate marked reduction in the amount of transcript encoding the protein, a finding that suggests pretranslational control. Significantly more transcript was present in a subject with a demonstrated posttranslational biosynthetic defect in LPH processing. The extent to which either of these mechanisms, alone or in combination, regulate the programmed decline of intestinal LPH in defined population groups or determine its variable expression over the longitudinal axis of the human intestine remains to be explored.

\section{Acknowledgments}

We are indebted to Dr. Lawrence Kahan and Vilja Lorenzsonn for their invaluable assistance in the preparation of monoclonal antibodies. We also thank Dr. Henry Pitot for his generous contribution of technical support.

This work was supported by grant AM-13927 from the National Institute of Arthritis, Diabetes, and Digestive and Kidney Diseases, by National Cancer Institute grant CA 22484-13, by Veterans Administration Research Funds, by the Swiss National Science Foundation, Berne, and by Nestlé Nutrition, Vevey. Dr. Lloyd was supported by National Institutes of Health Clinical Investigator Award K08 DK01789.

\section{References}

1. Sebastio, G., M. Villa, R. Sartorio, V. Guzzetta, V. Poggi, S. Auricchio, W. Boll, N. Mantei, and G. Semenza. 1989. Control of lactase in human adult-type hypolactasia and in weaning rabbits and rats. Am. J. Hum. Genet. 45:489-497.

2. Freund, J.-N., I. Duluc, and F. Raul. 1989. Discrepancy between the intestinal lactase enzymatic activity and $m R N A$ accumulation in sucklings and adults. FEBS (Fed. Eur. Biochem. Soc.) Lett. 248:39-42.

3. Buller, H. A., M. J. C. Kothe, D. A. Goldman, S. A. Grubman, W. V. Sassak, P. T. Matsudaira, R. K. Montgomery, and R. J. Grand. 1990. Coordinate expression of lactase-phlorizin hydrolase mRNA and enzyme levels in rat intestine during development. J. Biol. Chem. 265:6978-6983.

4. Witte, J., M. Lloyd, V. Lorenzsonn, H. Korsmo, and W. Olsen. 1990. The biosynthetic basis of adult lactase deficiency. J. Clin. Invest. 86:1338-1342.

5. Sterchi, E. E., P. R. Mills, J. A. M. Fransen, H.-P. Hauri, M. J. Lentze, H. Y. Naim, L. Ginsel, and J. Bond. 1990. Biogenesis of intestinal lactase-phlorizin hydrolase in adults with lactose intolerance. J. Clin. Invest. 86:1329-1337.

6. Dahlqvist, A. 1968. Assay of intestinal disaccharidases. Anal. Biochem. 22:99-107.

7. Lloyd, M. L., and W. A. Olsen. 1987. A study of the molecular pathology of sucrase-isomaltase deficiency. A defect in the intracellular processing of the enzyme. N. Engl. J. Med. 316:438-442.

8. Burke, T., M. Lloyd, V. Lorenzsonn, and W. Olsen. 1988. Synthesis and 
intracellular processing of aminooligopeptidase by human intestine. Gastroenterology. 94:1426-1431.

9. Laemmli, U. K. 1970. Cleavage of structural proteins during the assembly of the head of the bacteriophage T4. Nature (Lond.). 227:680-685.

10. Heukeshoven, J., and R. Dernick. 1985. Simplified method for silver staining of proteins in polyacrylamide gels and the mechanism of staining. Electrophoresis. 6:103-112.

11. Chomczynski, P., and N. Sacchi. 1987. Single-step method of RNA isolation by acid guanidinium thiocyanate-phenol-chloroform extraction. Anal. Biochem. 162:156-159.

12. Sambrook, J., E. F. Fritsch, and T. Maniatis. 1989. Molecular Cloning: A Laboratory Manual. Cold Spring Harbor Laboratory, Cold Spring Harbor, NY. 7.43-7.45.

13. Mantei, N., M. Villa, T. Enzler, H. Wacker, W. Boll, P. James, W. Hunziker, and G. Semenza. 1988. Complete primary structure of human and rabbit lactase-phlorizin hydrolase: implications for biosynthesis, membrane anchoring and evolution of the enzyme. EMBO (Eur. Mol. Biol. Organ.) J. 7:2705-2713.

14. Gunning, P., P. Ponte, H. Okayama, J. Engel, H. Blau, and L. Kedes. 1983. Isolation and characterization of full-length $\mathrm{cDNA}$ clones for human $\alpha-, \beta$ and $\gamma$-actin mRNAs: skeletal but not cytoplasmic actins have an amino-terminal cysteine that is subsequently removed. Mol. Cell. Biol. 3:787-795.

15. Herrmann, B. G., and A.-M. Frischauf. 1987. Isolation of genomic DNA.
In Methods in Enzymology. Vol. 152. Guide to Molecular Cloning Techniques. S. L. Berger and A. R. Kimmel, editors. Academic Press, New York. 180-183.

16. Kreitman, M., and L. F. Landweber. 1989. A strategy for producing single-stranded DNA in the polymerase chain reaction. Gene Anal. Tech. 6:84-88.

17. Bol, W., P. Wagner, and N. Mantei. 1991. Structure of chromosomal gene and cDNAs coding for lactase-phlorizin hydrolase in humans with adult-type hypolactasia or persistence of lactase. Am. J. Hum. Genet. 48:889-902.

18. Sanger, F., S. Nicklen, and A. R. Coulson. 1977. DNA sequencing with chain-terminating inhibitors. Proc. Natl. Acad. Sci. 74:5463-5468.

19. Welsh, J. D., J. R. Poley, M. Bhatia, and D. E. Stevenson. 1978. Intestinal disaccharidase activities in relation to age, race, and mucosal damage. Gastroenterology. 75:847-855.

20. Freund, J.-N., I. Duluc, and F. Raul. 1991. Lactase expression is controlled differently in the jejunum and ileum during development in rats. Gastroenterology. 100:388-394.

21. Maiuri, L., V. Raia, J. Potter, D. Swallow, M. W. Ho, R. Fiocca, G. Finzi, M. Cornaggia, C. Capella, A. Quaroni, and S. Auricchio. 1991. Mosaic pattern of lactase expression by villous enterocytes in human adult-type hypolactasia. Gastroenterology. 100:359-369.

22. Grosveld, F., G. B. vanAssendelft, D. R. Greaves, and G. Kollias. 1987. Position-independent, high-level expression of the human B-globin gene in transgenic mice. Cell. 51:975-985. 